\title{
Pille beskytter mot hivsmitte
}

\section{To piller før sex og to piller etter sex reduserer risikoen for hivsmitte blant menn som har sex med menn, viser ny studie.}

I en dobbeltblind studie ble 400 menn som har sex med menn randomisert til antiretroviral profylaktisk behandling eller placebo (1). De ble tatt inn til samtale om smittebeskyttelse og fikk utdelt kondomer og en boks med piller med instruks om å ta to piller før og to etter sex. Ved oppfølging hadde



Illustrasjonsfoto: Scanpix

\section{Skal feber hos intensivpasienter behandles?}

Bruk av paracetamol reduserer

ikke liggetiden hos intensivpasienter med feber og infeksjon, viser ny studie.

Paracetamol er vårt mest brukte medikament mot feber, også i intensivenheter. Feber kan ha en ønsket biologisk funksjon hos intensivpasienter med infeksjon. Skal da slike pasienter behandles med paracetamol eller ikke?

I en ny multisenterstudie publisert i New England Journal of Medicine har man forsøkt å avklare dette spørsmålet (1). 700 pasienter med mistenkt eller erkjent infeksjon og feber $>38^{\circ} \mathrm{C}$ ble randomisert til behandling med eller uten paracetamol. Behandlingen varte til feberen forsvant, pasienten ble utskrevet eller utviklet en kontraindikasjon mot paracetamol, døde eller fikk seponert antibiotika, og ble i alle tilfeller avsluttet etter 28 dager.

Etter 28 og 90 dager var det ingen forskjeller mellom gruppene i antall liggedager eller mortalitet. Det var ingen forskjell på de med seg pilleboksen, antall piller ble telt og mennene ble testet for hivinfeksjon og andre seksuelt overførbare infeksjoner.

I løpet av oppfølgingsperioden på ni måneder (median) ble det oppdaget 16 hivtilfeller, to i intervensjonsgruppen og $14 \mathrm{i}$ placebogruppen. De som hadde fătt antiretroviral behandling, rapporterte mer mageplager og nyreproblemer enn de som hadde fătt placebo, men ikke flere alvorlige bivirkninger.

- Dette er en svært relevant studie og en del av grunnlaget for at vi nå går inn for medikamentell preeksponeringsprofylakse, såkalt PrEP-behandling, også i Norge, sier Bente Magny Bergersen, som er overlege og seksjonsleder ved Infeksjonsmedisinsk poliklinikk ved Oslo universitetssykehus, Ullevål. - Rundt $90 \%$ av norske hivpasienter er i praksis ikke smittsomme, men likevel har vi en pågående hivepidemi blant menn som har sex med menn. Det er derfor gledelig når nye «verktøy» mot hivsmitte viser seg å ha effekt. At medisinen kan tas ved behov, gjør den spesielt interessant.

- Hivnegative menn med risikoatferd bør tilbys preeksponeringsprofylakse i kombinasjon med prøvetaking, rådgivning og kondomer. Vi håper at et slikt tilbud vil lokke flere menn som har sex med menn til hyppigere testing. Økt testaktivitet vil redusere antall nye hivtilfeller. Det er grundig dokumentert i flere studier, sier Bergersen.

\section{Martine Rostadmo \\ Tidsskriftet}

\section{Litteratur}

1. Molina JM, Capitant C, Spire B et al. On-demand preexposure prophylaxis in men at high risk for HIV-1 infection. N Engl J Med 2015; 373: 2237-46.

Publisert først på nett. antall dager i live, varighet av intensiv- og sykehusoppholdet, varighet av respiratorbehandling, bruk av vasopressor eller dialyse mellom gruppene. Man fant derimot en assosiasjon mellom paracetamol og kortere intensivopphold hos dem som overlevde, og lengre sykehusopphold hos dem som døde.

- Styrken med denne studien er at den er stor og randomisert og skulle dermed være egnet til å gi sikre svar, sier Tor Inge Tønnessen, professor og overlege ved intensivavdelingen ved Oslo universitetssykehus. - Svakhetene ved studien er bl.a. at det ble gitt paracetamol i et svært kort tidsrom, median mindre enn to dager, og Kaplan-Meier-plotene tyder på en effekt av paracetamol de to første dagene. Det er derfor ikke avklart om behandling med paracetamol over lengre tid er hensiktsmessig.

Tønnessen påpeker at paracetamol i de gitte dosene ikke var særlig effektiv til å redusere feber, siden det var mindre enn $0,2{ }^{\circ} \mathrm{C}$ i forskjell mellom gruppene, og at studien derfor ikke er egnet til å besvare spørsmålet om effektiv senkning av temperatur gir bedre utfall.
- En annen begrensning er at pasientgruppen er heterogen. Det er mulig man kunne sett en effekt ved kun å undersøke sepsispasienter, i tråd med resultater fra en tidligere studie, sier Tønnessen.

Bør man så gi paracetamol ved feber og smerter hos intensivpasienter? - Siden det ikke bedrer utfall, bør man kanskje være tilbakeholden. På den annen side er det viktig å redusere ubehag ved feber og smerte. Det var ingen forskjell i bivirkninger mellom paracetamol og placebo i studien, heller ikke forekomst av leverpåvirkning, sier Tønnessen. Han konkluderer med at man trygt kan bruke paracetamol for symptomlindring hos intensivpasienter.

\section{Ketil Slagstad}

Tidsskriftet

\section{Litteratur}

1. Young P, Saxena M, Bellomo R et al. Acetaminophen for Fever in Critically III Patients with Sus pected Infection. N Engl J Med 2015; 373: 2215-24. 